\title{
Non-invasive Ventilation in Adults: A Brief Update
}

\section{Leonardo S Roever-Borges* and Elmiro santos Resende}

Department of Clinical Research, Federal University of Uberlândia, Av. Pará, 1720-Bairro Umuarama, Uberlândia - MG - CEP 38400-902, Brazil

\begin{abstract}
The use of noninvasive ventilation and noninvasive continuous positive airway pressure by mask has increased substantially. The main indications are exacerbation of chronic obstructive pulmonary disease (COPD), cardiogenic pulmonary oedema, trauma, pulmonary infiltrates in immunocompromised patients, and weaning of previously intubated stable patients with COPD. In this mini-review article, we summarize the results of various studies in which noninvasive ventilation was applied and discuss the role and efficacy of noninvasive ventilation.
\end{abstract}

Keywords: Acute respiratory distress syndrome; Noninvasive ventilation; Respiratory failure

\section{Background}

Noninvasive ventilation (NIV) refers to positive pressure ventilation

\begin{tabular}{|c|c|}
\hline $\begin{array}{l}\text { Signs and symptoms of acute } \\
\text { respiratory distress }\end{array}$ & Gas exchange abnormalities \\
\hline \multicolumn{2}{|c|}{ Indications } \\
\hline $\begin{array}{l}\text { Moderate to severe dyspnea } \\
\text { RF } \geq 24 \\
\text { Signs of increased work of breathing, } \\
\text { paradoxical breathing or the use of } \\
\text { accessory muscles }\end{array}$ & $\begin{array}{l}\text {. } \mathrm{pH}<7,35 \text { with } \mathrm{PaCO}_{2}>45 \mathrm{mmHg} \\
\text {. Hypoxemia with } \mathrm{PaO}_{2} / \mathrm{FIO}_{2}<200 \\
\text { mmHg }\end{array}$ \\
\hline \multicolumn{2}{|c|}{ Contraindications to NIV } \\
\hline $\begin{array}{l}\text { Severe upper gastrointestinal bleeding } \\
\text { and postoperative esophageal } \\
\text { surgeries. } \\
\text {.Severe Encephalopathy (GCS < 10) } \\
\text {. Respiratory or cardiac arrest } \\
\text {.High risk for aspiration and inability to } \\
\text { clear secretions } \\
\text {.Trauma, deformity, facial or } \\
\text { neurological surgery } \\
\text {.Patient decline } \\
\text {.Unable to fit mask }\end{array}$ & $\begin{array}{l}\text { Unstable cardiac arrhythmia and } \\
\text { hemodynamic instability } \\
\text {.Organ failure } \\
\text {.Upper airway obstruction } \\
\text {.Inability to protect airway or cooperate } \\
\text {.Severe psychomotor agitation and } \\
\text { uncooperative patient. } \\
\text {.Hypotensive shock } \\
\text {.Total upper airway obstruction } \\
\text {. Need for emergency intubation }\end{array}$ \\
\hline \multicolumn{2}{|c|}{ Complications of NIV } \\
\hline Related to the mask & Related airflow or pressure generated \\
\hline $\begin{array}{l}\text { Discomfort } \\
\text { Claustrophobia } \\
\text {.Edema or erythema } \\
\text {.Ulceration of the nose bridge } \\
\text {. Leaks }\end{array}$ & $\begin{array}{l}\text {.Nasal congestion } \\
\text {.Local pain } \\
\text {.Nasal dryness and /or oral } \\
\text {.Conjunctivitis } \\
\text {.Gastric distension }\end{array}$ \\
\hline \multicolumn{2}{|c|}{ Risk factors for failure of NIV } \\
\hline $\begin{array}{l}\text { Age }>65 \text { years } \\
\text { Glasgow }<11 \\
\text { Tachypnea ( }>35 \text { bpm) } \\
\text { pH }<7,25 \\
\text { APACHE }>29 \\
\text { APACHE II score }>12 \text { at the time of } \\
\text { extubation. } \\
\text { Asynchrony with the ventilator } \\
\text { Absence of teeth } \\
\text { Multiple organ failure } \\
\text { Pneumonia } \\
\text { Cardiac failure as the cause of } \\
\text { intubation. } \\
\text { Chronic cardiac failure. } \\
\text { Arterial partial carbon dioxide pressure } \\
>45 \text { mmHg after extubation. } \\
\text { Patients with neuromuscular diseases } \\
\text { Obese patients }\end{array}$ & $\begin{array}{l}\text { Excessive leakage; } \\
\text { Agitation; } \\
\text { Hypersecretive patients; } \\
\text { Intolerance by the patient; } \\
\text { Lack of improvement in the first two } \\
\text { hours: maintenance of tachypnea and } \\
\text { respiratory distress, no improvement in } \\
\text { PaCO2 and pH. } \\
\text { Chronic respiratory disease with } \\
\text { ventilation }>48 \text { hours and hypercapnia } \\
\text { during spontaneous breathing trial. } \\
\text { Acute exacerbation of chronic } \\
\text { obstructive pulmonary disease. } \\
\text { Multiple comorbidities. } \\
\text { Weak cough or stridor after extubation. } \\
\text { Hypercapnia }\end{array}$ \\
\hline
\end{tabular}

Table 1: GCS: Glasgow Comma Scale, RF: respiratory frequency. delivered through a noninvasive interface (nasal mask, facemask, or nasal plugs), and it is used in patients with chronic hypercapnic respiratory failure caused by chest wall deformity, neuromuscular disease, COPD, posttraumatic hypoxemic respiratory failure, obesity hyperventilation syndrome, hypercapnic encephalopathy syndrome, non-hypercapnic respiratory failures or impaired central respiratory drive [1-5].

NIV has now become an integral tool in the management of both acute and chronic respiratory failure, in both the home setting, emergency room and in the intensive care unit [6-8].

The advantages of NIV over mechanical ventilation (MV) include the elimination of possible complications associated with endotracheal intubation, reduced incidence of infections related to MV, maintenance of speech and swallowing, greater comfort and flexibility of use to the patient as well as the preservation the defense mechanisms of the airway [9-11].

The consensus of the American Association of Respiratory Care endorses the use of NIV if 2 or more of the criteria are present (Table 1) $[12-17]$.

The main types of ventilation modes for noninvasive support are shown in Table 2 [15-17].

\begin{tabular}{|l|l|}
\hline Modes & Description \\
\hline BIPAP & $\begin{array}{l}\text {. Flow cycled } \\
\text {. Two pressure levels (IPAP and EPAP) } \\
\text { CPAP }\end{array}$ \\
\hline Spontaneous ventilation \\
. Constant airway pressure
\end{tabular}

Table 2: Types of ventilation modes for NIV. BIPAP - bilevel positive airway pressure, IPAP - inspiratory positive airway pressure; EPAP - expiratory positive airway pressure.CPAP - continuous positive airway pressure.

*Corresponding author: Leonardo S. Roever-Borges, Department of Clinical Research, Federal University of Uberlândia, Av. Pará, 1720-Bairro Umuarama, Uberlândia - MG - CEP 38400-902, Brazil, Tel: +553488039878; E-mail: leonardoroever@hotmail.com

Received June 08, 2015; Accepted December 10, 2015; Published December 16 2015

Citation: Roever-Borges LS, Resende ES (2015) Non-invasive Ventilation in Adults: A Brief Update. J Pulm Respir Med 5: 299. doi:10.4172/2161-105X.1000299

Copyright: () 2015 Roever-Borges LS, et al. This is an open-access article distributed under the terms of the Creative Commons Attribution License, which permits unrestricted use, distribution, and reproduction in any medium, provided the original author and source are credited. 


\begin{tabular}{|c|c|}
\hline Level of evidence & Clinical condition \\
\hline $\begin{array}{l}\text { Level } 1 \text { - Recommendation based } \\
\text { on randomized clinical trials and } \\
\text { systematic reviews }\end{array}$ & $\begin{array}{l}\text { Exacerbation of COPD } \\
\text { Acute cardiogenic pulmonary edema } \\
\text { Weaning and extubation in COPD patients } \\
\text { Hypoxic respiratory failure in } \\
\text { immunocompromised patients } \\
\text { Hypoventilation syndrome of obesity } \\
\text { Posttraumatic hypoxemic respiratory failure } \\
\text { Weaning strategy in adults with respiratory } \\
\text { failure } \\
\text { Reintubation rate in patients undergoing } \\
\text { cardiothoracic surgery } \\
\text { Prehospital noninvasive ventilation for acute } \\
\text { respiratory failure } \\
\text { Acute respiratory failure due to chest trauma. }\end{array}$ \\
\hline $\begin{array}{l}\text { Level } 2 \text { - Recommendation based } \\
\text { on systematic review of cohort } \\
\text { studies }\end{array}$ & $\begin{array}{l}\text { Patients who refuse intubation, terminally ill } \\
\text { and on palliative care } \\
\text { Extubation failure prevention in patients } \\
\text { with COPD or acute cardiogenic pulmonary } \\
\text { edema } \\
\text { Community-acquired pneumonia in patients } \\
\text { with COPD; } \\
\text { Asthma } \\
\text { Respiratory failure in postoperative } \\
\text { (prevention and treatment) }\end{array}$ \\
\hline $\begin{array}{l}\text { Level } 3 \text { - Systematic review of } \\
\text { case-control studies }\end{array}$ & $\begin{array}{l}\text { Neuromuscular disease and kyphoscoliosis } \\
\text { Partial obstruction of the upper airways } \\
\text { Chest trauma } \\
\text { Prevent or to treat perioperative acute } \\
\text { respiratory failure }\end{array}$ \\
\hline $\begin{array}{l}\text { Level } 4 \text { - Number of cases (cohort } \\
\text { study and case-control) }\end{array}$ & $\begin{array}{l}\text { Cystic fibrosis } \\
\text { Hypercapnic encephalopathy syndrome } \\
\text { Amyotrophic lateral sclerosis. } \\
\text { Non-COPD and non-trauma patients with } \\
\text { acute hypoxemic respiratory failure } \\
\text { Exercise tolerance in heart failure } \\
\text { Acute respiratory failure in delirious patients }\end{array}$ \\
\hline
\end{tabular}

Table 3: Level of evidence and clinical condition. COPD: chronic obstructive pulmonary disease.

NIV is an important option in the management of patients who are at risk of or who have respiratory failure in the acute and chronic sharpened care setting (Table 3).

\section{References}

1. Maheshwari V, Paioli D, Rothaar R, Hill NS (2006) Utilization of noninvasive ventilation in acute care hospitals: a regional survey. Chest 129: 1226-1233.

2. Demoule A, Girou E, Richard JC, Taillé S, Brochard L (2006) Increased use of noninvasive ventilation in French intensive care units. Intensive Care Med 32 1747-1755.

3. Baudouin S, Blumenthal S, Cooper B, Davidson C, Davison A, et al. (2002) Non-invasive ventilation in acute respiratory failure. Thorax 57: 192-211.

4. Ellis ER, Bye PT, Bruderer JW, Sullivan CE (1987) Treatment of respiratory failure during sleep in patients with neuromuscular disease: positive pressure ventilation through a nose mask. Am Rev Respir Dis 135: 523-524.

5. Kerby GR, Mayer LS, Pingleton SK (1987) Nocturnal positive pressure ventilation via nasal mask. Am Rev Respir Dis 135: 738-740.

6. Goodacre S, Stevens JW, Pandor A, Poku E, Ren S, et al. (2014) Prehospital noninvasive ventilation for acute respiratory failure: systematic review, network meta-analysis, and individual patient data meta-analysis. Acad Emerg Med 21 960-970.

7. Bakke SA, Botker MT, Riddervold IS, Kirkegaard H, Christensen EF (2014) Continuous positive airway pressure and noninvasive ventilation in prehospital treatment of patients with acute respiratory failure: a systematic review of controlled studies. Scand J Trauma Resusc Emerg Med 22: 69.

8. Mehta S, Hill NS (2001) Noninvasive ventilation. Am J Respir Crit Care Med 163: 540-577.

9. Girou E, Schortgen F, Delclaux C, Brun-Buisson C, Blot F, et al. (2000) Association of noninvasive ventilation with nosocomial infections and survival in critically ill patients. JAMA 284: 2361-2367.

10. Girou E, Brun-Buisson C, Taillé S, Lemaire F, Brochard L (2003) Secular trends in nosocomial infections and mortality associated with noninvasive ventilation in patients with exacerbation of COPD and pulmonary edema. JAMA 290: 2985-2991.

11. Chandra D, Stamm JA, Taylor B, Ramos RM, Satterwhite L, et al. (2012) Outcomes of noninvasive ventilation for acute exacerbations of chronic obstructive pulmonary disease in the United States, 1998-2008. Am J Respir Crit Care Med 185: 152-159.

12. Keenan SP, Sinuff T, Burns KE, Muscedere J, Kutsogiannis J, et al. (2011) Clinical practice guidelines for the use of noninvasive positive-pressure ventilation and noninvasive continuous positive airway pressure in the acute care setting. CMAJ 183: E195-214

13. Lemyze M, Taufour P, Duhamel A, Temime J, Nigeon O, et al. (2014) Determinants of noninvasive ventilation success or failure in morbidly obese patients in acute respiratory failure. PLoS One 9: e97563.

14. Mas A, Masip J (2014) Noninvasive ventilation in acute respiratory failure. Int $J$ Chron Obstruct Pulmon Dis 9: 837-852.

15. Romero-Dapueto C, Budini H, Cerpa F, Caceres D, Hidalgo V, et al. (2015) Pathophysiological Basis of Acute Respiratory Failure on Non-Invasive Mechanical Ventilation. Open Respir Med J 9: 97-103.

16. Ozyilmaz E, Ugurlu AO, Nava S (2014) Timing of noninvasive ventilation failure: causes, risk factors, and potential remedies. BMC Pulm Med 14: 19.

17. Barbas CS, Isola AM, Farias AM, Cavalcanti AB, Gama AM, et al. (2014) Brazilian recommendations of mechanical ventilation 2013. Part I. Rev Bras Ter Intensiva 26: 89-121. 